\title{
Growth and abscission of avocado fruits (Persea americana Mill.) cv. Fuerte
}

\author{
RODOLFO B. MUÑOZ PEREZ, LESZEK S. JANKIEWICZ*, \\ CARLOS ACOSTA-ZAMUDIO \\ Departamento de Fitotecnia, Universidad Autónoma Chapingo, \\ 56230 Chapingo, Méx., Mexico
}

(Received 1987.01.13)

\begin{abstract}
In a commerical orchard of 18-year-old trees, 1250 fruits were chosen for observation. The majority of them abscised during the first weeks after anthesis. Afterwards, the atkcission gradually descreased, however, in the meantime three additional waves of more intensive shedding occurred which were best visible when the Relative Abscission Rate (RAR) was calculated. The peaks in the RAR curve were preceded by a decrease in the Relative Growth Rate (RGR) of persistent fruits, which suggests that nutritional or other stresses occurred in the whole branch. In the period from May 15th to July 15th, predominantly the smaller fruits were abscised. later on. however, fruits of the same size as the persistent ones were shed. The formula for calculating RAR and RAR is shortly discussed.
\end{abstract}

\section{INTRODUCTION}

Avocado trees set a great number of flowers, of which only a very low per cent give mature fruits, according to Papademetriou (1976) only 0.04$0.66 \%$. The final crop depends largely on premature fruit abscission.

The abscission of young fruits is considered to be a natural phenomenon in plants of many species, since usually a plant sets more fruits that it can feed (Plich, 1979). Little information exists concerning the abscission of avocado fruits. In avocado cv. Hass heavy abscission takes place during the first weeks of fruit growth and the 2 nd peak occurs in mid-summer (Adato and Gazit, 1977). In avocado cv. Fuerte there were at least three periods of heavier abscission (Blumenfeld and Gazit, 1974). However, Slabbert (1981) in South Africa has found a dome shaped curve of weekly total abscised fruits of cv. Fuerte.

* Permanent address: Research Institute of Vegetable Crops, 96-100 Skierniewice, Poland, where requests for reprints should be sent. 
The scope of this work was to give a detailed description of avocado fruit abscission in central Mexico, since the existing descritpions were rather general and were done in remote countries (Israel and South Africa). The other purpose was to compare the relative growth curve with the relative abscission curve of avocado fruits to check if in this species each abscission wave is preceded by a decrease in the growth of permanent fruits as was found in orange (Zucconi et al., 1978) and in apple trees (Poma Treccani et al., 1982).

\section{METERIAL.AND METHODS}

The investigation was performed in a commercial avocado orchard in Tenancingo, Méx $\left(18^{\circ} 58^{\prime} \mathrm{N}, 99^{\circ} 36^{\prime} \mathrm{E}, 2080 \mathrm{~m}\right.$ above sea level). The climate of the region is moderate with a long dry period (Fig. 1). This made irrigation

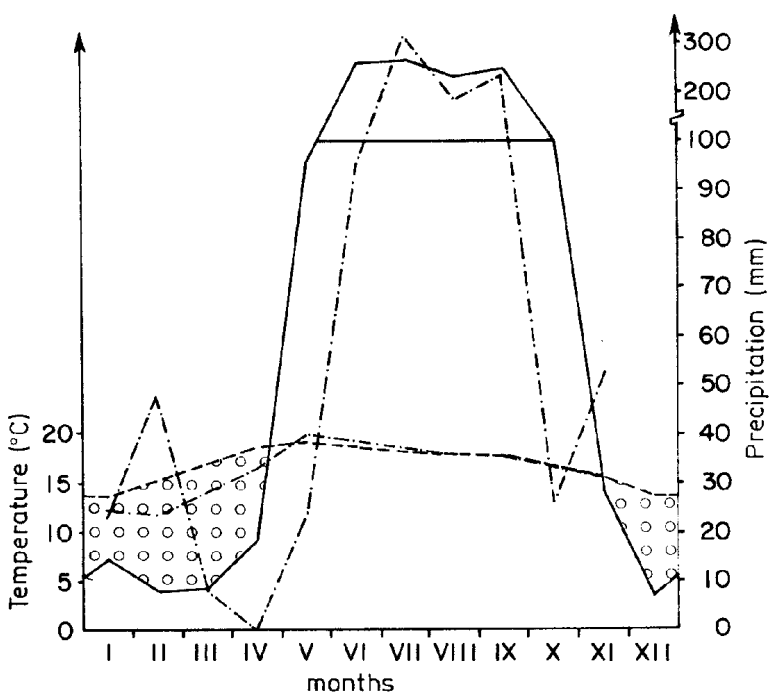

Fig. 1. Monthly ombrothermic diagram of Tenancingo, Mex. for the period 1929-1960, according to Garcia (1981). The circles indicate drought. The data for 1983 marked with dasheddotted line. The method of presentation according to Walter and Leith (1960)

indispensable during the dry months. The symbol of the Tenancingo climate is $\mathrm{Cw}_{2}^{\prime \prime}\left(\mathrm{w}(\mathrm{b}) \mathrm{i}^{\prime}\right) \mathrm{g}$ according to Garcia (1981). The trees were growing in a deep, fertile loamy soil, with a spacing of $11 \times 9 \mathrm{~m}$. The fruits $(1250)$ were chosen in the northern part of the crowns of five 18-year-old trees. The reason for chosing only the fruitlets growing on the northern branches was that blooming occurred on different dates depending on the position of the branch in the crown. The branches with the northern exposition flowered 2-3 
weeks later than those situated in the southern or apical parts of the crown (Table 1). The fruitlets were chosen for observation on April 14, i.e. shortly after the end of anthesis. The fruitlets were at that time $5 \mathrm{~mm}$ long or less. At that date only the fruits originating from the spring period of flowering were

\section{Table 1}

Development of buds and flowers on avocado branches exposed to the north (N) or to the south (S) on the same avocado trees. Observations on $1985.01 .16^{+}$. Results in percentages

\begin{tabular}{|c|c|c|c|c|c|c|c|c|}
\hline \multirow[t]{2}{*}{ Tree No. } & \multicolumn{2}{|c|}{$\begin{array}{l}\text { Compact } \\
\text { inflores- } \\
\text { cences }^{++}\end{array}$} & \multicolumn{2}{|c|}{$\begin{array}{c}\text { Expanded } \\
\text { inflorescence } \\
\text { axes only buds }\end{array}$} & \multicolumn{2}{|c|}{$\begin{array}{l}\text { Opened } \\
\text { flowers }\end{array}$} & \multicolumn{2}{|c|}{$\begin{array}{c}\text { Post } \\
\text { anthesis }\end{array}$} \\
\hline & $\mathbf{N}$ & $S$ & $\mathbf{N}$ & $S$ & $\mathbf{N}$ & $\mathbf{S}$ & $\mathbf{N}$ & $\mathrm{S}$ \\
\hline 1 & 46.3 & 0 & 29.6 & 4.6 & 24.1 & 4.6 & 0 & 90.8 \\
\hline 2 & 32.1 & 0 & 42.9 & 0 & 15.5 & 0 & 9.5 & 100.0 \\
\hline 3 & 42.3 & 0 & 35.2 & 0 & 22.5 & 6.3 & 0 & 93.7 \\
\hline 4 & 40.3 & 0 & 37.1 & 0 & 22.6 & 8.0 & 0 & 92.0 \\
\hline
\end{tabular}

All trees in the orchard behaved similarly. These 4 trees were chosen randomly as examples. Similar phenomena were observed in April and in December of 1983. In 1984 we did not observe the trees.

++ The axes of the inflorescence were not expanded and the inflorescence was forming a bud which started to open.

present on the trees. Probably due to a cold period in winter, when the temperatures descended to -1 , almost all inflorescences in the northern part of the trees bloomed at the same time. This phenomenon greatly facilitated the investigation.

During the course of the investigation, the number of fruits gradually decreased and we had to add some fruits to the investigated population: 46 fruits on May 24, 8 fruits on June 14 and 7 fruits on September 14. These fruits were of a size very similar to that of the fruits which had been chosen initially, and behaved similarly. In the further text and in the figures, it is indicated if the given result pertains to the population of fruits chosen initially or to the fruits aggregated later. The measurements of the fruits were made initially every 5-11 days and later every 10-16 days. The maximum diameter of the fruits was measured only from June 14, i.e. when the fruits had already changed their form, from nearly round to oblong. From May 13 the length and the diameter of the peduncle were also measured. The nomenclature of the different parts of a peduncle is explained in Figure 6. The final harvest of the fruits was done on November 25. At this date all fruits which had persisted were transferred to the laboratory and immediately opened to check whether seed coats and seeds were disintegrated. The results presented pertain only to the fruits which were healthy at harvest. Nevertheless, abscising fruits almost always showed some darkening of the seed coats, a phenomenon known in literature. 
Relative Growth Rate (RGR) of the persistent fruits was calculated according to the formula commonly applied in the mathematical analysis of plant growth (Hunt, 1982; Pietkiewicz, 1985 a,b). The Relative Abscission Rate (RAR) was calculated in an analogous manner as RGR assuming, however, that abscission is a kind of "negative increase" (decrease of the fruit number on the tree). Thus, the formula for the instantaneous values of RAR which we used was:

$$
\operatorname{RAR}=\frac{1}{N_{1}} \frac{\left(N_{1}-N_{2}\right) 100}{T_{2}-T_{1}},
$$

where $N_{1}$ and $N_{2}$ denote the number of fruits at the two consecutive dates $T_{1}$ and $T_{2}$. The result is expressed as the percent of abscised fruits per day.

The formula which we propose for the mean values of RAR is analogous to that of $\overline{\mathrm{RGR}}$, taking into consideration that RAR presents a negative increase, as mentioned above.

$$
\overline{\mathrm{RAR}}=\frac{\left(\log _{e} N_{1}-\log _{e} N_{2}\right) 100}{T_{2}-T_{1}} .
$$

The comparision of RAR and $\overline{\text { RAR }}$ values in our experiment is shown in Figure 2. In the further text we use the instantaneous values of RAR.

The correlation coefficient was calculated between RAR and RGR and their regression line taking $R G R$ as an independant variable.

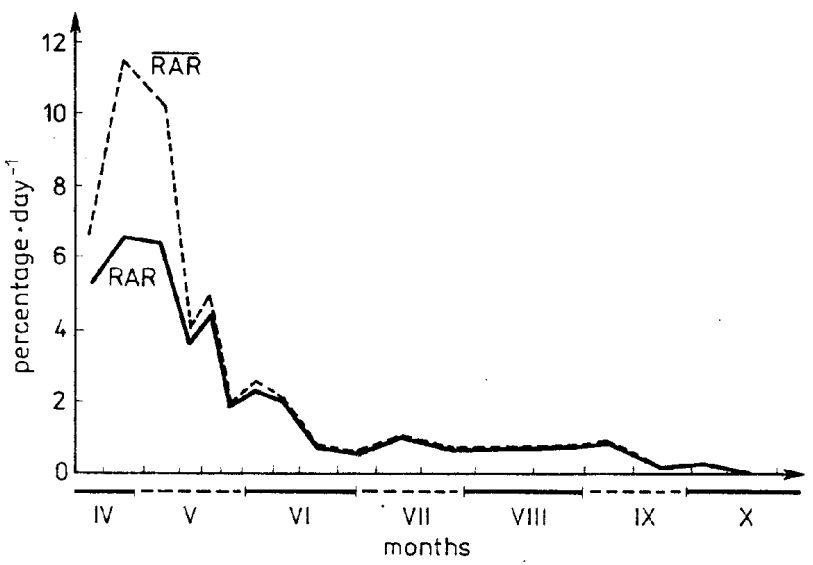

Fig. 2. Relative Abscission Rate expressed in instantaneous values (RAR) and in mean values ( $\overline{\text { RAR }})$

\section{RESULTS}

The cumulative growth curve of the persistent avocado fruits had a simple sigmoide shape (Fig. 3) as was also shown by other authors (Schroeder, 1953; Valmayor, 1967; Blumenfeld and Gazit, 1974). The 


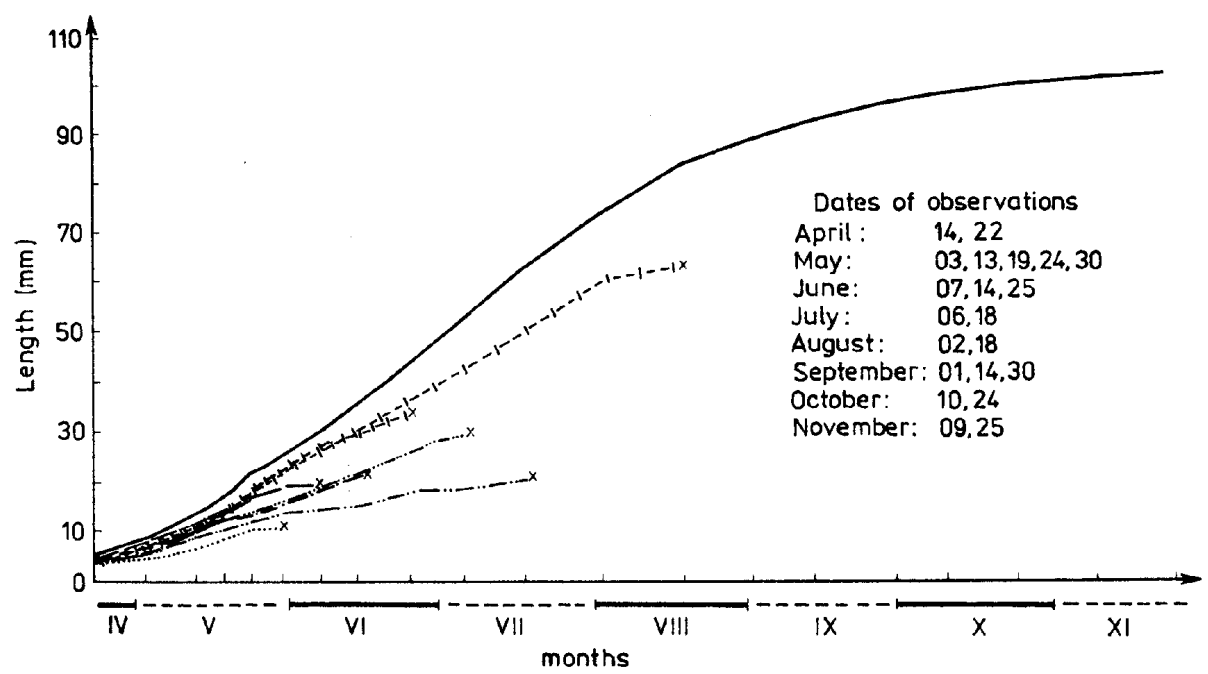

Fig. 3. Growth in lenght: of the persistent fruits (solid line) and of fruits which were shed at different dates (interrupted lines); $\mathbf{x}$ - abscission. Dates of observation are marked on the abscissa (population of fruits chosen on April 14)

final size of the fruits was on average $10.2 \mathrm{~cm}$ in length and $5.5 \mathrm{~cm}$ in diameter, meaning that the fruits were rather small in the year of investigation.

Fruit abscission was very heavy during the first weeks after anthesis and afterwards decreased gradually, ceasing completely on October 10, i.e. one and a half month before harvest. The time course of the fruit drop is better visualized by the RAR curve (Fig. 4). The RAR was very high during the first weeks after anthesis (first wave of abscission) showing afterwards a gradual decrease interrupted by three additional waves of more intensive fruit drop: in the second part of May, about June 7 to 14 and in mid-July.

The RAR curve was almost parallel to that of the RGR of persistent fruits (Fig. 4). Correlation between RAR and RGR was very high: 0.938 . The relation between these two variables is of the simple linear type, its regression line estimated by the method of minimum squares has the equation RAR $=-0.2595+0.9936$ RGR.

As may be seen in Figure 4 each period of more intensive abscission (except, of course, the first one) was preceded by a decrease of RGR of persistent fruits occurring 1-3 weeks earlier.

Initially the larger fruits were abscised easier (Fig. 5), however, after May 3 and up to mid-July, there was a reverse tendency: the smaller fruits having lower growth rates were shed more (Fig. 3). The fruits which were abscised showed a tendency to slow their growth 1-2 weeks before abscission.

The fruits which were abscised during the period from July to midOctober usually showed a similar size and initial growth rate as the 


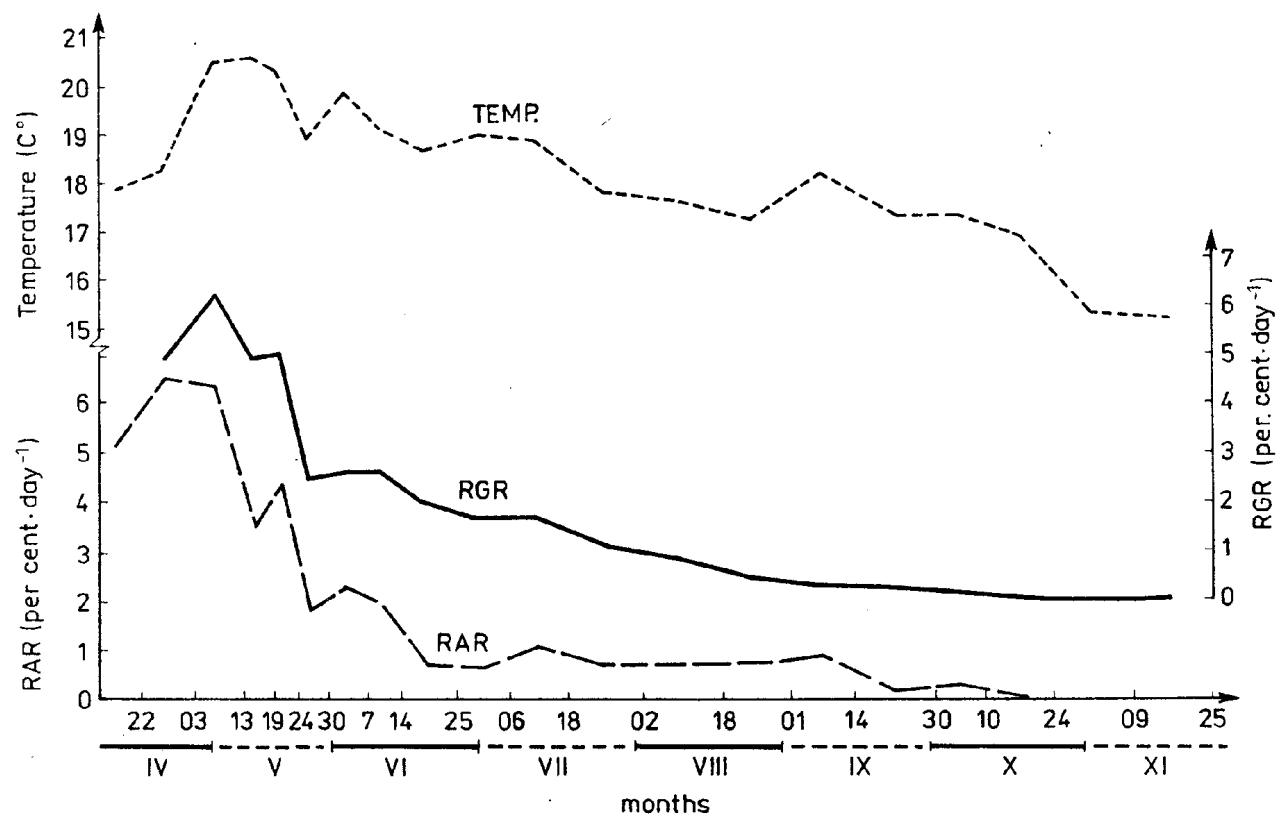

Fig. 4. The curves: of Relative Growth Rate (RGR) of persistent fruits and Relative Abscission Rate (RAR). Temperature was calculated as an average for each interval between the two consecutive measurements of fruit number. (Population of fruits chosen on April 14)

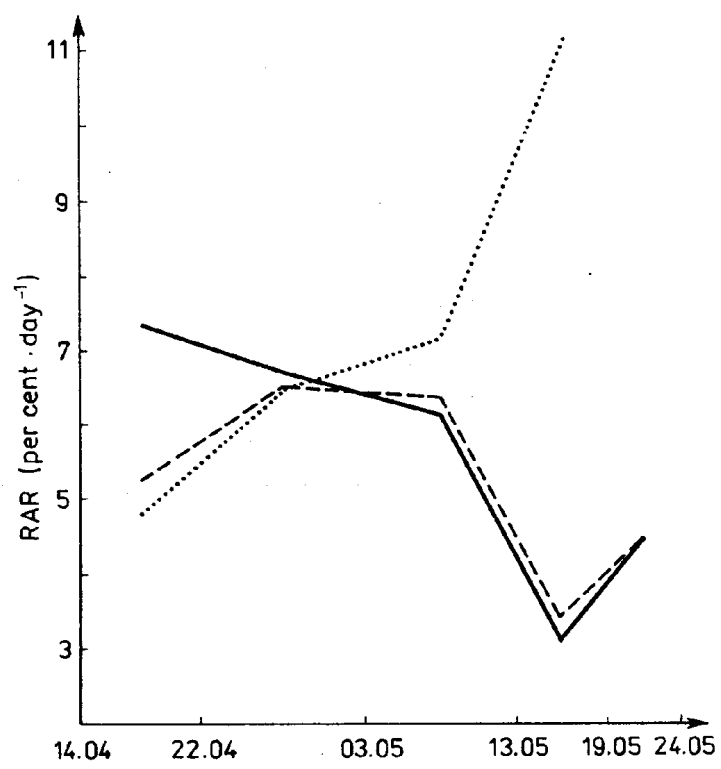

Fig. 5. Relative Abscission Rate during the first month of fruit development. Fruits larger than $5 \mathrm{~mm}$ (solid line), smaller than $5 \mathrm{~mm}$ (dotted line) and total (dashed line). (Population of fruits chosen on April 14) 
persistent fruits. They demonstrated, however, a decrease of their growth rate 2-4 weeks before abscission (Fig. 6).

Thickening of the peduncle in the fruits which were abscised in May to mid-July was inhibited (Fig. 7). The fruits which were shed after mid-July (not shown in Fig. 7) had peduncles as thick as the persistent fruits.

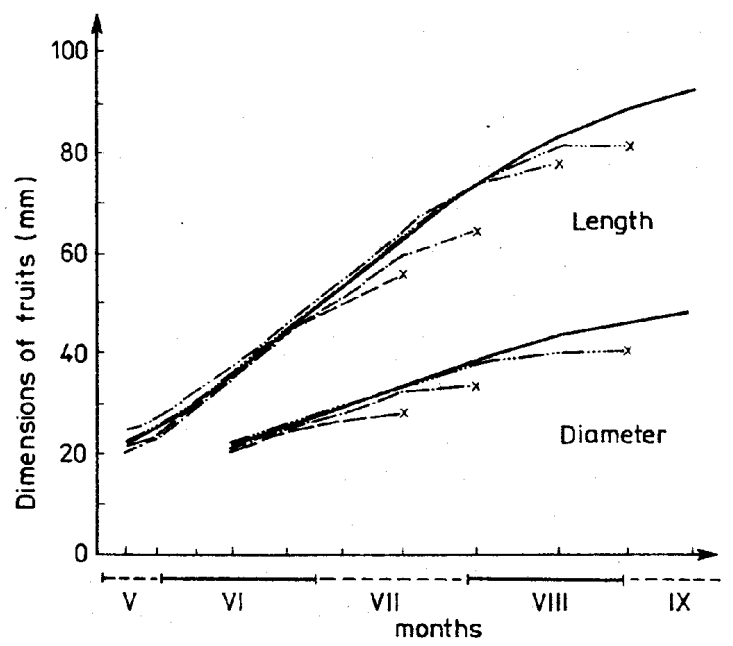

Fig. 6. Growth of persistent fruits (solid line) and of those which were shed between July and September (interrupted lines). Dates on the abscissa as in Fig. 3. (Population of fruits chosen on May 24)

Fig. 7. Thickening of the peduncle in the persistent fruits (solid lines) and in those which were abscised at different dates (dashed lines). $\mathbf{S}$ - slender, and $\mathbf{T}$ thick part of the peduncle. Dates on the abscissa as in

Fig. 3. (Population of fruits chosen on April 14)

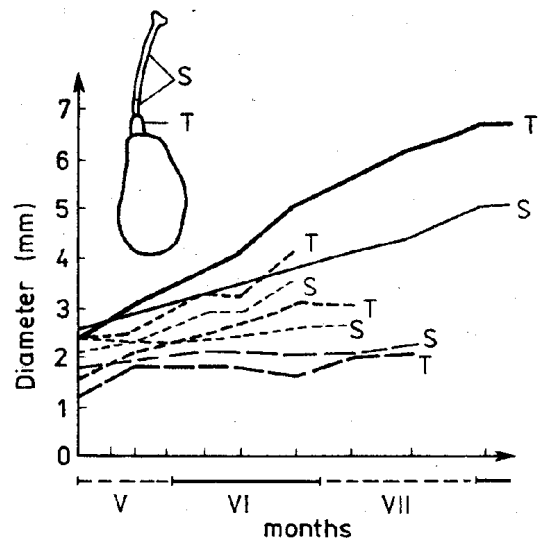

\section{DISCUSSION}

Our data on fruit abscission may be compared to those of Adato and Gazit (1977) obtained in Israel with cv. Hass. Abscission in both investigations was similar in that it was very abundant during the first weeks after 
anthesis, decreased gradually thereafter, and ceased completely some weeks before harvest. This decreasing tendency was interrupted in cv. Hass by one wave of heavy abscission, about 3 months after fruit set. In our experiment with cv. Fuerte there were 3 periods of more intensive abscission that coincided well with the data of Blumenfeld and Gazit (1974) obtained with the same cultivar. As mentioned, Slabbert (1981) obtained a domeshaped curve of abscission. He investigated, however, the abscission of fruits from the whole tree, and due to this, his results can not be compared directly with ours, since it is known that different inflorescences in the crown differ with their blooming dates (compare for instance Table 1).

Also in several other species of fruit trees, the periods of heavier abscission alternate with periods of little abscission or no abscission (Westwood, 1978), for instance in apple (Magein 1983; Poma Treccani et al., 1982) and in orange ( $\mathrm{Zucconi}$ et al., 1978). There are, however, different views as to the cause of these fluctuations. Luckwill (1953) put forward a hypothesis that the periods of heavy abscission coincide with periods of low levels of hormones in the seeds. On the other hand, there exists much data indicating that competition for nutrients (or for other factors) among fruitlets or between fruitlets and other organs greatly influences abscission (Plich, 1979).

Analysing the aforementioned problem of competition, $\mathrm{Zucconi}$ et al. (1978), Poma Treccani 1982 et al. (1982) and Magein (1983) compared the RGR curve of persistent fruits with that of RAR in order to check if there is any relation between the two. The introduction of these indices to the investigation of abscission seems very useful since it enables a more precise evaluation of interrelations between the time course of growth and the time course of abscission. The concept of RGR has been used for many years in the mathematical analysis of plant growth, however, it was rarely applied to fruits (Hunt, 1982). The concept of RAR was introduced to literature, as far as we know, by Zucconi et al. (1978). They use for RAR the same formula as for RGR. We have modified it slightly to make it more convenient (see Material and Methods). Magein (1983) applied a different formula for RAR than Zucconi et al. (1978) and the authors of the present paper. According to Magein, $\operatorname{RAR}=\left(N_{1}-N_{2}\right):\left(N_{i}-N_{f}\right)$ d, where $N_{i}$ and $N_{f}$ denote fruit numbers at the beginning of the experiment and at harvest, respectively, and "d" denotes the number of days elapsed between two measurements at time 1 and time 2. The mean values of RAR, as far as we know, were not applied by other authors.

Comparison of the curves of RGR of persistant fruits and of RAR in our experiment showed their striking parallelism. It was evident that each wave of abscission was preceded by a depression in the growth rate of persisting fruits. Our results with avocado (Fig. 4) show, therefore, astonishing similarities to the results obtained with oranges ( $Z$ ucconi et al., 1978), and with apples (Poma Treccani et al., 1982) in which similar parallelism was 
found. Since avocado, organe and apple trees belong to remote families from the point of view of systematics, it is probable that the phenomenon is of rather common occurrence and that it may be found in trees of other species.

Zucconi (1981) and Zucconi et al. (1978) considered the period of inhibited growth of persistent fruits preceding the abscission wave as a symptom of strees occurring in the whole tree. For instance in orange trees, part of the leaves are shed during this period (Erickson and Brannaman, 1960); in apple trees, the growth of the shoots is also inhibited and the weaker shoots fall into dormancy (Poma Treccani et al., 1982). There are indirect data indicating that this stress is caused by competition for nutrients or hormones produced in other parts of the plant (compare Plich 1979; Zucconi 1981). There were even trials undertaken to use photosynthesis inhibitors to thin the fruitlets (Byers et al., 1985). The theoretical basis for their experiment was that they wanted to aggravate the natural nutritional stress causing a shortage of assimilates in fruitlets.

Recently Berüter (1985) presented results which are seemingly contradictory to the conception that competition for nutrients plays an important role in the regulation of premature abscission of fruitlets. He found no difference in carbohydrate concentration in apple fruitlets with a higher and those with a lower tendency to be abscised (these last ones were larger). Nevertheless, this lack of difference was partly elucidated by Manolov and Maximov (1985) who have shown that the supply of ${ }^{14} \mathrm{C}$-assimilates was proportional to fruitlet weight during the early stage of fruit development. Thus, in this stage the larger fruitlets received more assimilates than the smaller ones in spite of the fact that the specific radioctivity was almost the same for all fruits. Only later (28 days after full bloom) did the larger fruitlets show higher specific radioactivity than the smaller ones.

We put forward the following hypothesis attempting to explain the parallel fluctuations of RGR and RAR (Fig. 8):

a. As the fruitlets are growing, their tissues augment their volume and, at least for some time, their cell number (in avocado fruit cell number augments up to maturity). Due to this, their demand for nutrients and for hormones produced in other organs, increases. Some factors may become deficient in this situation and the fruitlets begin to compete for them. Sometimes they compete with other organs also, such as growing shoots, young roots, etc. Finally, an acute deficiency (a deficiency stress) may appear, which causes growth limitation in all fruitlets, shoots, etc.

b. When the deficiency stress crosses some threshold value, the formation of an abscission zone is initiated in some of the fruitlets (compare $\mathrm{Zucconi}$, 1981). The fruitlets which occupy less favorable, from a nutritional point of view, positions in the cluster or those which have a lower number of vascular strands in their peduncles (Habdas et al., 1982) are less resistant to the 


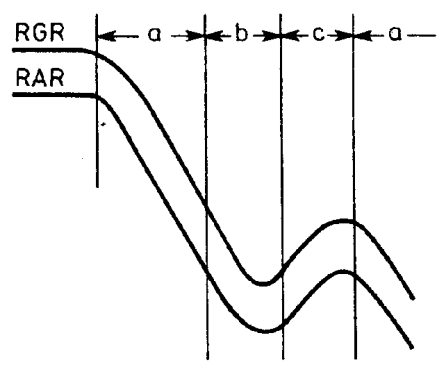

Fig. 8. Illustration to the hypothesis attempting to explain the parallel fluctuations of RGR and RAR. a - shows the phase in which the competition among fruitlets for nutrients or other factors gradually increases which causes inhibition of their growth; the fruitlets in which the abscission layer was formed during the preceding phase terminate to be shed; $b$ - in this phase the deficiency of nutrients or other factors is deepest, the abscission layer forms in most stressed fruitlets: $c$ - fruitlets in which the abscission layer has been formed abscise, and immediately

the remaining ones liberated from the competition, start to grow faster

aforementioned stress and form an abscission zone (compare $\mathrm{Zucconi}$ et al., 1978; Poma Treccani et al., 1982; Magein, 1983).

c. Some days or weeks after the initiation of an abscission zone part of the fruitlets is shed. The remaining fruitlets are immediately released from the stress and begin to grow faster. Simultaneously, the stimulation to form an abscission zone is withheld and only those in which the formation of separation stratum is advanced, are abscised (see Jankiewicz, 1985).

$a^{\prime}$. As the fruits which remain on the tree are growing intensely, augmenting their volume and continuing their development (seed formation etc.), their demand for nutrients gradually increases, leading to a new deficiency stress and a new cycle "a-c".

This hypothesis is based on our results and on those of Zucconi et al. (1978), Poma Treccani et al. (1982) and Magein (1983). It also summarizes their interpretations.

The hypothesis that explains changes in the abscission rate by competition among fruitlets does not exclude the correctness of Luckwill's hypothesis which suggests that fluctuations in the hormonal balance of the seeds are connected with the abscission waves. Periodic changes in the hormone balance of fruits are probably connected with fluctuations in fruit ability to synthesize hormones. Both these factors: competition for nutrients and fluctuating ability to synthesize harmones may jointly regulate fruitlets abscission. For instance, when the actual hormone balance of the fruits temporarily restrains their abscission, the deficiency stress may greatly increase causing later heavier abscission. As mentioned, the fruitlets may suffer not only from dificiency of nutrients (or water) but also of hormones supplied from other parts of the plant. 
The problem - which fruit will be shed first requires discussion. Several authors have shown that in orange and in apple trees the smaller fruits are shed preferentially (Zucconi et al., 1978; Zucconi, 1981; Poma Treccani et al., 1982; Magein 1983). The presented results have shown that in avocado trees this phenomenon also occurs but not in all periods. During the first two weeks after fruit set (April 14-May 3) even the opposite phenomenon was observed: the larger fruits were shed more often: possibly the smaller fruits, which in this case were a few days younger, could have more sink power for nutrients.

From May 3 to mid-July the smaller avocado fruits were abscised easier. Smaller fruits also had a thinner peduncle, which may mean that they were supplied with less nutrients. It is claimed by several authors that smaller fruits are less resistant to deficiency stress since their growth is more inhibited during stress conditions (Magein, 1983; Zucconi et al., 1978; Poma Treccani et al., 1982).

When the weaker fruits had been already shed (after mid-July) and only fruits of a similar size remained on the tree, part of them were also shed. In this case probably the position of the fruit on the branch might be a decisive factor.

If competition plays an important role in the regulatory mechanism of fruitlet abscission, a tentative conclusion may be drawn for horticultural practice: competition may occur for any factor(s) which becomes deficient, for instance assimilates, water, nitrogen, zinc etc. In some cases or in some species the fruitlets may also compete for cytokinins produced in roots or for other hormones. To prevent abscission, the deficient factor should be recognized and supplied. In cases where thinning is necessary an artificial deficiency may be evoked by manipulating with fertilization or by suppressing the supply of assimilates to the fruitlets (Byers et al., 1985).

\section{Acknowledgements}

The authors are greatly indebted to Dr. M. Engelman and M. Sc. R. Nieto Angel for valuable suggestions, to Ing. L. Serrano Covarrubias and to $\mathrm{Dr}$ R. Zając for help with the statistical and mathematical problems and to Ing. A. Díaz Ballesteros for kindly providing us with facilities for conducting the investigation in his avocado orchard.

\section{REFERENCES}

Adato I., Gazit S., 1977. Role of ethylene in the avocado fruits development and ripening. I. Fruit Drop. J. Exp. Bot. 28: 636-43.

Berüter J., 1985. Sugar accumulation and changes in the activities of related enzymes during development of apple fruit. J. Plant Physiol. 121: 331-41.

Blumenfeld A., Gazit S., 1974. Development of seeded and seedless avocado fruits. J. Amer. Soc. Hort. Sci. 99: 442-448. 
Byers R. E., Lyons C. G. Jr, Yoder K. S., Barden J. A., Young R. W., 1985. Peach and apple thinning by shading and photosynthetic inhibition. J. Hort. Sci. 60: 465-472.

Davenport T. L., Manners M. M., 1982. Nuclear senescence and ethylene production as they relate to avocado fruit abscission. J. Exp. Bot. 33: 815-25.

Erickson L. C., Brannaman B. L., 1960. Abscission of reproductive structures and leaves of orange trees. Proc. Amer. Soc. Hort. Sci. 75: 222-229.

García E., 1981. Modificaciones al sistema de clasificación climatica de Köppen (para adaptarlo a las condiciones de la República Mexicana) E. García de Miranda, Indianapolis 30, México 18, D. F.

Habdas H., Jankiewicz L. S., Borkowska B., 1982. Changes in anatomical structures of apple fruitlet pedicels preceding June drop. Acta Agrobot. 35: 11-23.

Hunt R. 1982. Plant growth curves. Edward Arnold, London.

Jankiewicz L. S. 1985. Mechanism of abscission of leaves and reproductive parts of plants a model. Acta Soc. Bot. Pol. 54: 285-322.

Luckwill L. C. 1953. Studies of fruit development in relation to plant hormones. I. Hormone production by the developing apple seed in relation to fruit drop. J. Hort. Sci. 28: 14-24.

Magein H. 1983. Dynamiques de croissance et d'abscission chez la pomme cultivar Cox's Orange Pippin. Bul. Rech. Agron. Gembloux 18: 173-187.

Manolov R., Maximov N. 1985. The relation between type of fruits-bearing wood and fruit supply with assimilates in cv. Golden Delicious [in Bulg.]. Rastenievidni Nauki (Sofia) 22 (9): 109-116.

Papademetriou M. K. 1976. Percentage fruit set in avocados (Persea americana Mill.). California Avocado Soc. Yearboook 59: 135-142.

Pietkiewicz S. 1985a. Growth analysis of plants [in Polish]. Wiad. Bot. 29: 29-42.

Pietkiewicz S. 1985b. Experimental and calculation techniques in growth analysis of plants [in Polish]. Wiad. Bot. 29: 111-126.

Plich H. 1979. Rozwój owocu. [In:] Fizjologia roślin sadowniczych. L. S. Jankiewicz (ed.) PWN, Warszawa, pp. 462-508.

Poma Treccani C., Bellini C., Malandra F., Varisco B., Visai C., Zucconi F. 1982. Dinamica dell'abscisione nei frutti di melo: relazioni con lo sviluppo della lamburda della freccia e del fruto. Riv. Ortoflorofrutt. It. 66: 147-160.

Schroeder C. A. 1953. Growth and development of the Fuerte avocado fruit. Proc. Amer. Soc. Hort. Sci. 61: 103-109.

Slabbert M. J. 1981. Flower and fruit drop. Yearbook South Afr. Avocado Growers Assoc. 4: 89-90.

Valmayor R. V. 1967. Cellular development of the avocado from blossom to maturity. Philippine Agriculturist. 50: 907-976.

Walter H., Leith H. 1960. Klimadiagram Weltatlas. Fisher Verlag, Jena.

Westwood M. N. 1978. Temperate zone pomology. W. G. Freeman and Co., San Francisco, USA.

Zucconi F., 1981. Regulation of abscission in growing fruit. Acta Horticulture 120: 89-94.

Zucconi F., Monselise S. P., Goren R. 1978. Growth abscission relationship in developing orange fruit. Scientia Horticulturae 9: 137-146.

\section{Wzrost i zrzucanie owoców awokado (Persea americana Mill.) odmiany Fuerte}

\section{Streszczenie}

W 18-letnim sadzie handlowym wybrano do obserwacji na pięciu drzewach 1250 zawiązków owoców. Większość z nich została zrzucona w pierwszych tygodniach po kwitnieniu. Potem zrzucanie stopniowo słabło, zaobserwowano jednak trzy fale silniejszego zrzucania, które najbar- 
dziej uwidoczniły się, gdy obliczono wskaźnik opadania względnego (RAR). Szczyty na krzywej RAR były poprzedzone około tydzień wcześniej spadkiem wzrostu względnego (RGR) owoców nieopadających, które przetrwały aż do zbioru. Świadczyło to, że opadanie poprzedzone jest przez stres żywieniowy (niedostatek węglowodanów lub innych składników) lub inny rodzaj stresu w calej badanej gałęzi. W okresie od 15 maja do 15 lipca głównie opadały owoce mniejsze, ale później także owoce tej samej wielkości co owoce trwale pozostające na drzewie (aż do zbiorów). Zaproponowano wzory dla RAR i $\overline{\text { RAR. }}$. 